\title{
VAIKŲ SUBJEKTYVIOJO SVEIKATOS VERTINIMO IR GYVENIMO KOKYBËS SĄRYŠIO KONCEPTUALIZAVIMAS
}

\author{
Jūratė Grubliauskiene் ${ }^{1}$, Rita Vaičekauskaitė ${ }^{1}$, Almeda Kuriené ${ }^{2}$, Natalja Fatkulina ${ }^{2}$ \\ ${ }^{1}$ Klaipédos universitetas, ${ }^{2}$ Vilniaus universiteto Medicinos fakulteto Sveikatos mokslu institutas
}

Raktažodžiai: vaikai, gyvenimo kokybè, sveikata, subjektyvusis sveikatos vertinimas.

\section{Santrauka}

Subjektyvusis sveikatos vertinimas pradètas tyrinèti $\mathrm{XX}$ amžiaus aštuntajame dešimtmetyje. Atlikta įvairių tyrimų, tačiau juos sunku sujungti ị konceptualią visumą, nes stokojama metodologinio nuoseklumo ir teorinio konceptualumo. Vieni tyrejjai subjektyvujji sveikatos vertinimą siūlo laikyti papildomu šalia objektyvių medicinos duomenų, kiti mano jị esant ne mažiau svarbiu už medicininę diagnozę. Subjektyvusis sveikatos vertinimas nèra savaiminis reiškinys, jo raiška priklauso nuo socialinių psichologinių veiksnių, kurių sąveikos kompleksiškumą suvokti padeda gyvenimo kokybės, kaip socialinės sistemos, tyrimai. Ryškèja tendencija, rodanti gyvenimo kokybès ir sveikatos vertinimo tarpusavio sąryšio neapibrèžtumą, kai beveik „,visi neklinikiniai duomenys apie žmogų prilyginami gyvenimo kokybei“ [3]. Nors sveikata laikoma viena svarbiausių gyvenimo kokybès dimensijų, ji nebūtinai nulemia gyvenimo kokybès vertinimą. Yra atvejų, kai neiggalieji savo gyvenimo kokybę vertina gerai [7, 22-24]. Siekiant konceptualizuoti subjektyviojo sveikatos vertinimo sąsajas su gyvenimo kokybe, plètojama su sveikata susijusios gyvenimo kokybès sąvoka, apibrèžianti, kaip žmonès ,suvokia ir reaguoja ị savo sveikatos būklę ir su sveikata susijusius veiksnius, tokius kaip fizinè, funkciné, emocinè, psichinè gerové, bei su sveikata tiesiogiai nesusijusius veiksnius, tokius kaip darbas, šeima, draugai ir kt.“ [24].

Straipsnyje pateikiama vaikų subjektyviojo sveikatos vertinimo sąryšio su gyvenimo kokybe analize, kuria siekama prisidèti prie subjektyviojo sveikatos vertinimo konceptualaus tyrinejimo problemos sprendimo. Tyrimo tikslas - empiriškai atskleisti vaikų ir tėvų subjektyviojo sveikatos vertinimo sąsajas su gyve- nimo kokybe lemiančiais veiksniais bei konceptualizuoti jų raišką su sveikata susijusios gyvenimo kokybės perspektyvoje.

Tyrime dalyvavo 11 Lietuvos mokyklų 2-12 klasių mokiniai ir jų tèvai. Imtis -1763 mokiniai ir 1564 jų tèvai. Tyrimui naudotas KIDSCREEN-52 klausimynas (išsami versija), iš kitų išsiskiriantis tuo, kad ji pildo ir tèvai, ir vaikai. Anketos koduotos jas poruojant. Duomenų analizei taikyti aprašomosios statistikos metodai, Student $t$ testas, Mann Whitney kriterijus, Spearman ranginès koreliacijos koeficientas, Wilcoxon kriterijus.

Tyrimo rezultatai parodė subjektyviojo sveikatos vertinimo sąsajų su gyvenimo kokybe raišką: du trečdaliai vaikų nurodè neturintys sveikatos sutrikimų, tačiau tik vienas trečdalis savo sveikatą ịvertino puikiai ir labai gerai. Prieita prie išvados, kad vaikų sveikatos įsivertinimui svarbus ne tik ligos ar negalios nebuvimas, bet ir psichologiniai bei socialiniai veiksniai, kurie formuoja su sveikata susijusią gyvenimo kokybę.

\section{Ivadas}

Sveikatos subjektyvusis vertinimas (angl. self-perceived health, subjective health assessment) igauna vis didesnès svarbos sveikatos stiprinimui, gydymui ir politikai. Tyrimų duomenys rodo ypač didelę subjektyviojo sveikatos vertinimo svarbą. Seni ir pagyvenę žmonès, prastai vertinę savo sveikatą, per ketverius metus mire šešis kartus dažniau, negu tie, kurie savo sveikatą vertino gerai. Prastas savo sveikatos vertinimas kelia kelis kartus didesnę mirties riziką, negu rūkymas [5]. Sveikatos subjektyviojo vertinimo svarbą parodo tai, kad žmogaus patiriamas distresas dèl ligos poveikio kasdieniam gyvenimui yra didesnis, negu dèl ligos simptomatikos [1].

Paplitęs požiūris, kad subjektyvusis sveikatos vertinimas papildo objektyvius tyrimų duomenis, skatina kurti kompleksinio sveikatos vertinimo modelius [12]. Yra manančių, kad subjektyvusis sveikatos vertinimas aprépia labai inte- 
gralų (genetika, požiūris, savijauta, šeimos istorija, aplinka, lūkesčiai ir kt.) žmogaus požiūrị i savo sveikatą, tad tokio pobūdžio vertinimo negalima atlikti pavienėmis tikslinėmis priemonèmis ar jų deriniu [1,5]. Vis geriau suvokiant subjektyviojo sveikatos vertinimo svarbą, formuojasi požiūris, kad subjektyvusis sveikatos vertinimas turetų pasitarnauti sveikatos politikos formavimui [26], ì pacientą orientuotos medicinos raidai [1], sveikatos priežiūros paslaugų kokybès gerinimui [18-19]. Tyrimai rodo, kad subjektyvusis sveikatos vertinimas koreliuoja su pasitenkinimu paslaugomis ta prasme, kad prasčiau savo sveikatą vertinantys žmonès išreiškia daugiau nepasitenkinimo sveikatos priežiūros paslaugomis $[10,18]$.

$2014 \mathrm{~m}$. Lietuvos gyventojų sveikatos statistinio tyrimo rezultatai apima tik vyresnių nei 15 metų jaunuolių subjektyvuji sveikatos vertinimą (angl. self-perceived health). Tyrimo rezultatai Lietuvoje rodo, kad kuo vyresni žmonès, tuo prasčiau jie vertina savo sveikatą. Kritinis lūžis, kai pradedama prastai vertinti sveikata, prasideda nuo 55 metų. Tyrimai rodo panašius prastėjančius gyvenimo kokybės rezultatus [27]. Gyvenimo kokybės išteklių ir rizikos sisteminis tyrimas Lietuvoje, apimantis vyresnius negu 18 metu asmenis, parodè, kad „kintant amžiui, gyvenimo kokybės ir socialinès sveikatos ištekliai mažèja, o rizika didèja“ [3]. Eurostat duomenimis, 2016 m. Lietuvos gyventojų savo sveikatos geras ar labai geras vertinimas buvo žemesnis, negu ES vidurkis. Subjektyvusis sveikatos vertinimas padeda paaiškinti sveikatos būklès ir gyvenimo kokybès santykio kompleksiškumą. Nors sveikata laikoma viena svarbiausių gyvenimo kokybès dimensijų, ji nebūtinai absoliučiai nulemia gyvenimo kokybès vertinimą. Tai rodo atvejai, kai neigalieji savo gyvenimo kokybę vertina gerai [7, 22-24]. Ypač trūksta duomenų apie subjektyviojo vaikų sveikatos vertinimo sąsajas su gyvenimo kokybės dimensijomis [20], tačiau esamieji tyrimai rodo tendencingas vaikų gyvenimo kokybės sąsajas su subjektyviuoju sveikatos vertinimu [21]. Siekiant konceptualizuoti subjektyviojo sveikatos vertinimo sąsajas su gyvenimo kokybe, pletojama nauja su sveikata susijusios gyvenimo kokybės samprata, aprėpianti savo sveikatos suvokimą, reakciją ị sveikatos būklę ir su ja susijusius fizinès, funkcinès, emocinès, psichinès sveikatos ir kitus veiksnius, tokius kaip darbas, šeima, draugai ir kt." [24].

Lietuvoje su sveikata susijusios gyvenimo kokybès tyrimai pastaraisiais metais vis aktyviau plètojami [3-4, 1517], tačiau dèmesio vaikams labai trūksta, nes daugiausia atliekama gerontologijos tyrimų $[9,25]$. Be to, tyrimuose su vaikais dažniausiai apklausiami jų tėvai ar globejai, todèl trūksta tyrimų, kuriuose ị klausimus atsakytų vaikai. KIDSCREEN-52 yra viena iš nedaugelio priemonių, kurią taikant $i$ tuos pačius klausimus atsako ir tèvai, ir vaikai. Nors kartais baiminamasi, kad vaikų atsakymai nebus objektyvūs, tyrimai rodo, kad vaikai jau nuo šešerių metu geba atsakyti i klausimus apie savo sveikatą [19]. Kuo vyresni vaikai, tuo labiau jie sieja sveikatą ne tik su biologiniais, bet ir su socialiniais veiksniais [13-14].

Tyrimo tikslas - empiriškai atskleisti vaikų ir tèvų subjektyviojo sveikatos vertinimo sąsajas su gyvenimo kokybe lemiančiais veiksniais bei konceptualizuoti jų raišką su sveikata susijusios gyvenimo kokybės perspektyvoje.

\section{Tyrimo medžiaga ir metodai}

Subjektyviojo sveikatos vertinimo konceptualaus tyrinėjimo problemai spręsti straipsnyje pateikiama vaikų subjektyviojo sveikatos vertinimo sąryšių su gyvenimo kokybe analizè, pagrista 1763 vaikų ir 1564 tėvų KIDSCREEN-52 anketinès apklausos duomenimis. Subjektyviojo sveikatos vertinimo sąsajų su gyvenimo kokybe raišką rodo tyrimo rezultatai: du trečdaliai vaikų nurodè neturintys sveikatos sutrikimų, tačiau tik trečdalis savo sveikatą ịvertino puikiai ir labai gerai. Tai rodo, kad vaikų sveikatai svarbus ne tik ligos ar negalios nebuvimas, bet ir psichologiniai bei socialiniai veiksniai, kurie formuoja su sveikata susijusią gyvenimo kokybę.

Gyvenimo kokybės reikšmė subjektyviajam sveikatos vertinimui. Subjektyvusis sveikatos vertinimas nèra toks intravertiškas reiškinys, kaip gali atrodyti. Tai rodo tyrimai, kuriuose subjektyvusis sveikatos vertinimas siejamas su reitingavimu (angl. self-rated health), pvz., kaip jūs vertinate savo sveikatą, palyginus su bendraamžių, arba kaip vertinate savo sveikatą, atsižvelgiant ị tai, ką veikiate gyvenime. Subjektyvusis sveikatos vertinimas reitingavimo būdu atskleidè naują tendenciją, kai savo sveikatą, palygintą su bendraamžių, vyresni žmonès vertina geriau, negu jaunesni. Tai rodo, kad subjektyvusis sveikatos vertinimas yra glaudžiai susijęs su kontekstu [6].

Vis daugiau tyrimų siekia nustatyti reikšmingai savo sveikatos vertinimą lemiančius socialinius psichologinius veiksnius. Socialiniai veiksniai, pvz., emocinè parama, saugi aplinka, bendravimas ir pan., turi tiesiogini poveiki vaiko subjektyviajam sveikatos vertinimui [2]. Vaikai, gyvenantys socialinès rizikos aplinkoje, savo sveikatą vertina prasčiau. Tai gali būti viena iš priežasčių, kodèl Lietuvos vaikų savo sveikatos vertinimas yra prasčiausias Europoje (1 pav.).

Gyvenimo kokybės tyrimai galètų prisidèti prie konceptualaus požiūrio ị socialinių psichologinių veiksnių svarbą subjektyviajam sveikatos vertinimui formavimo raidos. M. Butikio požiūriu, gyvenimo kokybė turètų būti vertinama kaip socialinè sistema, atsižvelgiant i jos išteklių-rizikos santykį [3]. Tokio pobūdžio tyrimai gali suteikti daug vertingos informacijos apie ,svei- 
katos būklès riziką, ypač tais atvejais, kai prasidejusios ligos fizinių požymių dar neịmanoma apčiuopti“".

Gyvenimo kokybès dimensijų skaičius tokio pobūdžio tyrimų klausimynuose svyruoja nuo šešių iki dešimties [8]:

- fizinè gerovè, materialioji gerovè, socialinè gerovè, produktyvumo gerovè, teisès, emocinè gerovè (D. Felce, 1996);

- fizinè gerovè, materialioji gerovè, socialinè įtrauktis, emocinè gerovè, teisès, asmeninis tobulèjimas, apsisprendimas, tarpasmeniniai santykiai (R. Schalock, 2000);

- fizinè gerovè, aplinkos gerove, socialiniai santykiai, psichologinè gerovè, nepriklausomybès lygis, dvasinè gerovė (PSO, 1993);

- sveikata, materialioji gerové, darbas ir produktyvi veikla, emocinè gerové, bendruomeniškumas, santykiai su šeima ir draugais, asmeninis saugumas (M. Hagerty et al, 2001:74-75);

- sveikata, materialioji gerovè, bendruomeniškumas, darbas, emocinè gerovè, socialiniai- šeimos ryšiai, saugumas (R. Cummins, 1997);

- fizinè gerove, finansiniai ištekliai, socialinis palaikymas ir bendraamžiai, mokyklos aplinka, nuotaika ir emocijos, psichologinè gerovè, santykiai su tèvais, savarankiškumas, patyčios, savęs suvokimas (KIDSCREEN-52, The European kidscreen group, 2006).

Platus gyvenimo kokybės dimensijų spektras ịvairiose

1 pav. İvairių Europos šalių vaikų sveikatos įsivertinimo rezultatai Šaltinis: PSO (2017)

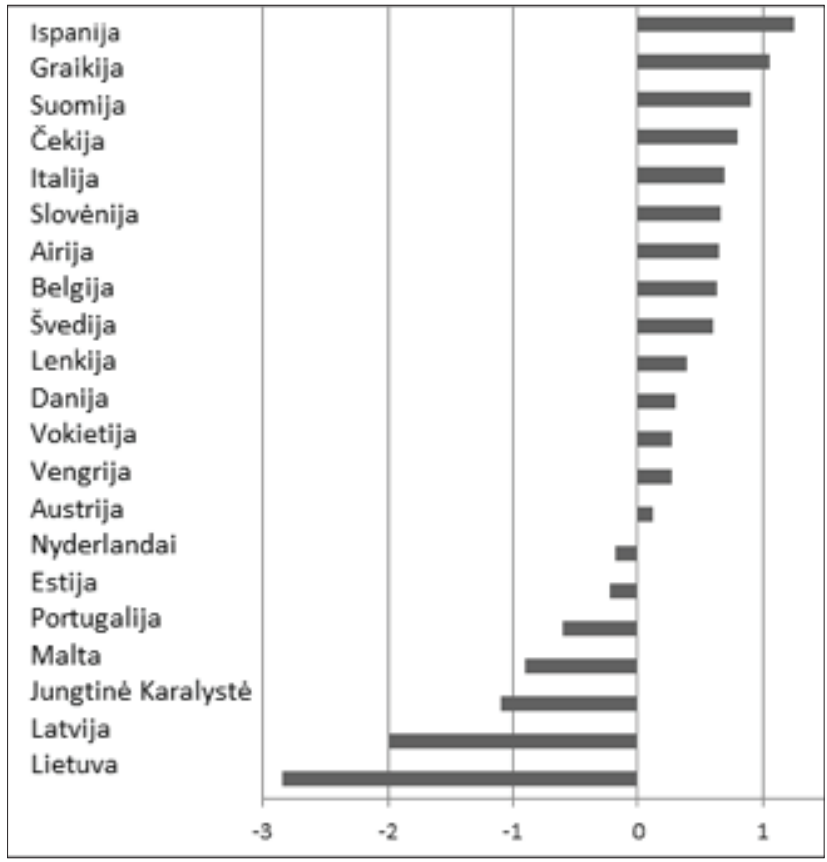

klausimynuose įgalina įvairiapusiškai modeliuoti subjektyviojo sveikatos vertinimo ir gyvenimo kokybès sąsajas.

\section{Tyrimo objektas ir metodai}

Tyrimas atliktas 2015 metais. Tyrimo imtis formuota vykdant mokyklų atranką. Naudojant SPSS programinę įrangą, atsitiktinių skaičių generatoriumi atrinkta 11 mokyklų (iš aštuonių Lietuvos savivaldybių, proporcingai išsidèsčiusių 5 Lietuvos regionuose). Tyrimui pasirinktas KIDSCREEN klausimynas, iš kitų išsiskiriantis tuo, kad ji pildo ne tik tèvai, bet ir patys vaikai. Klausimynas pateiktas visiems atrinktų mokyklų 2-12 klasių moksleiviams bei jų tėvams. Iš viso imti sudare 1763 vaikai ir 1564 tèvai [8]. Siekiant sisteminti duomenis šeimos aspektu, anketos koduotos jas poruojant, t.y., identiški kodai priskirti ir vaikų, ir tèvų klausimynams.

Respondentu pasiskirstymui pagal tirtas charakteristikas apskaičiuoti taikyti aprašomosios statistikos metodai; kintamujų grupiniams skirtumams nustatyti - Student $\mathrm{t}$ testas. Mann Whitney kriterijus taikytas siekiant nustatyti statistiškai reikšmingus skirtumus tarp nepriklausomo (vaiko lytis, neformalus savo sveikatos vertinimas, kalbejjimasis su tèvais apie sveikatą) ir priklausomo (su sveikata susijusios vaikų gyvenimo kokybės dimensijos) kintamuju. Spearman ranginès koreliacijos koeficientas taikytas siekiant nustatyti ryšius tarp vaiko amžiaus, subjektyviojo sveikatos vertinimo ir su sveikata susijusios vaikų gyvenimo kokybės dimensijų vertinimo. Wilcoxon kriterijus taikytas siekiant nustatyti, ar yra statistiškai reikšmingi skirtumai tarp vaikų, kurie kalbasi (ar nesikalba) su tèvais apie sveikatą ir su sveikata susijusios vaikų gyvenimo kokybės dimensijų ịsivertinimo.

1 lentelè. KIDSCREEN-52 klausimyno vaikams struktūra Šaltinis: Grubliauskienè (2019, p. 70)

\begin{tabular}{|l|c|c|}
\hline $\begin{array}{l}\text { Sociodemografiniai } \\
\text { duomenys }\end{array}$ & $\begin{array}{c}\text { Vaiko su sveikata susiju- } \\
\text { sios gyvenimo kokybės } \\
\text { dimensijos }\end{array}$ & $\begin{array}{c}\text { Matavimo } \\
\text { elementų } \\
\text { skaičius }\end{array}$ \\
\hline Lytis & Fizinè gerovè & 5 \\
\hline Amžius & Psichologinè gerovė & 6 \\
\hline $\begin{array}{l}\text { Kaip vertina savo } \\
\text { sveikatą }\end{array}$ & Nuotaikos ir emocijos & 7 \\
\hline $\begin{array}{l}\text { Ar kalbasi su tėvais } \\
\text { apie sveikatą }\end{array}$ & Savęs suvokimas & 5 \\
\hline & $\begin{array}{c}\text { Savarankiškumas } \\
\text { gyvenimas šeimoje }\end{array}$ & 5 \\
\hline & Finansiniai ištekliai & 3 \\
\hline & $\begin{array}{c}\text { Socialinis palaikymas ir } \\
\text { bendraamžiai }\end{array}$ & 6 \\
\hline & Mokyklos aplinka & 3 \\
\hline & $\begin{array}{c}\text { Socialinis prièmimas } \\
\text { (patyčios) }\end{array}$ & 3 \\
\hline
\end{tabular}




\section{Tyrimo aprašymas}

Tyrimui pasirinktas KIDSCREEN-52 klausimynas (išsami versija), kurị sudaro trys dalys: ịvadine (I), sociodemografinè (II), gyvenimo kokybės dimensijų vertinimas ir joms vertinti skirti matavimo elementai (III) (1 lentelè). Vaiku buvo klausiama apie jų lytị, amžių, pokalbius su tèvais apie sveikatą. Vaikų prašyta neformaliai ịsivertinti sveikatą, t.y., pažymèti, turi ar neturi sveikatos sutrikimą, ligą ar ilgalaikę negalią, neprašant to patvirtinti medicininiais dokumentais. Vaikų prašyta subjektyviai ịvertinti savo sveikatą. Galimi atsakymų variantai nuo „puiki“ iki „bloga“. Tėvų klausta apie išsilavinimą, darbo pobūdị, pajamas, šeiminę padètị, vaiko sveikatos sutrikimus, ar tèvai kalbasi su savo vaiku apie sveikatą. Tẻvų prašyta pažymèti, kaip, jų manymu, jų vaikas vertina savo sveikatą ir objektyviai įvertinti savo vaiko sveikatą, t.y. pažymèti, kokiai organų sistemai priskirtas konkretus atvejis, ar pasirinkti keletą sistemų (klausimyne pateikta galimybė pasirinkti vieną ar kelis sutrikimus, kurie įrašomi ị statistinès apskaitos formą Nr. 027-1/a „Vaiko sveikatos pažymejjimas“, išduodamą sveikatos priežiūros ịstaigos, atlikusios vaiko profilaktinị sveikatos tikrinimą).

Vadovaujantis KIDSCREEN group Europe metodika (2006), kiekviena su sveikata susijusios vaikų gyvenimo kokybès vertinimo subskalès skalè tapati matavimo vienetui - dimensijai. Pasirinktoji tyrimo priemonè leidžia vertinti 10 su sveikata susijusios vaiku gyvenimo kokybės dimensijų. Kiekvienai dimensijai vertinti skirta nuo 3 iki 7 matavimo elementų (klausimų). Atsakant ị klausimus, pateikiami 5 ranguojamų atsakymų variantai, kur 1 reiškia „visai ne“, o 5 - „урас̌“ arba 1 reiškia „,niekada“, o 5 - „visada“. Gauti atsakymų rezultatai interpretuojami vadovaujantis KIDSCREEN group Europe metodikoje pateiktu dimensijų vertinimo rezultatu interpretavimu.

Siekiant validaus priemonės taikymo, klausimynas išverstas pagal jo autoriu pateiktą vertimo metodiką [11]. Atliktas dvigubas vertimas iš anglų kalbos. Tévams ir vaikams skirto klausimyno tinkamumui įvertinti atliktas žvalgomasis tyrimas (140 respondentų, po 70 vaikų ir tėvų, dviejose mokyklose).

Priemonès vidinio suderinamumo vertinimas parodè, $\mathrm{kad}$ vaikams skirto klausimyno bendras suderinamumo rodiklis (Cronbach alfa) yra 0,848, o atskirų subskalių šis rodiklis svyruoja nuo 0,797 iki 0,890. Tévams skirto klausimyno bendrasis Cronbach alfa koeficientas 0,811, o atskirų subskalių - nuo 0,842 iki 0,907.

Tyrimo metu laikytasi visų tyrimams taikomų etinių reikalavimų. Tyrimas atliktas užtikrinus išsamų dalyvių informavimą, konfidencialumą ir savanorišką dalyvavimą.

Tyrimo rezultatai

Tyrime dalyvavo 1763 8-18 metų vaikai. Gautas labai panašus respondentų pasiskirstymas pagal lytị: 51,14 proc. mergaičių ir 48,86 proc. berniukų. Amžiaus grupès: 8-10 metų (17,9 proc.); $11-14$ metų (40,4 proc.); $15-18$ metų (41,6 proc.).

Nors 87,57 proc. tyrimo dalyvių nurode neturintys sveikatos sutrikimų ar ilgalaikès negalios, puikiai savo sveikatą ivertino 30,5 proc. respondentų. Sveikatą labai gerai įsivertino 26,27 proc. vaiku, gerai - 30,43 proc., kiti - patenkinamai arba blogai (atitinkamai 7,92 proc. ir 1,88 proc.). 87,02 proc. tiriamujų labai dažnai kalbasi su tèvais apie sveikatą, 12,98 proc. - nesikalba.

Tyrime dalyvavo 1564 8-18 metu vaikų tèvai. Analizuojant respondentų pasiskirstymą pagal išsilavinimą, nustatyta, jog dauguma $(38,5$ proc.) turi vidurinị išsilavinimą, šiek tiek daugiau nei penktadalis $(21,2$ proc.) - aukštajj universitetini, 17,1 proc. - aukštesniji, 9,8 proc. - nebaigtą vidurini, 9,3 proc.- aukštaji neuniversitetinị, 4,2 proc. - pradinị išsilavinimą.

Šeiminès padèties analizè parodè, jog didžioji dalis tèvų (72,7 proc.) gyvena kartu santuokoje arba nesusituokę, beveik penktadalis ( 18,0 proc.) išsiskyrę, kiti ( 5,6 proc.) - nesusituokę ir gyvenantys atskirai arba našliai (3,8 proc.).

Analizuojant tèvų kalbejimosi su vaikais apie sveikatą dažnumą, nustatyta, jog du trečdaliai $(59,1$ proc.) tai daro dažnai, kiti (38,1 proc.) - kartais kalbasi arba niekad (2 proc.) nesikalba su savo vaikais apie sveikatą. Tévų klausta, kaip, jų manymu, vaikas ịvertintų savo sveikatą. Ketvirtadalis (25,7 proc.) apklaustujų pažymėjo, vaikas įvertintų sveikatą puikiai, ketvirtadalis $(25,0$ proc. $)$ - jog vaikas galvoja, kad jo sveikata labai gera, 41,0 proc. tèvų atsaké, kad jų vaikas savo sveikatą ịvertintų gerai, 7,9 proc. - patenkinamai ir tik 0,9 proc. apklaustujų mané, kad jų vaikas savo sveikatą vertina blogai.

Subjektyviojo sveikatos vertinimo ryšiai su gyvenimo kokybės dimensijomis. Vaikų su sveikata susijusios gyvenimo kokybès įsivertinimas ir subjektyvusis sveikatos vertinimas. Tyrimo metu siekta nustatyti su sveikata susijusios vaiku gyvenimo kokybės ịsivertinimo ir subjektyviojo sveikatos vertinimo ryšį. Statistiškai reikšmingos tiesioginès koreliacijos nustatytos tarp vaikų subjektyviojo sveikatos ir šių vaikų su sveikata susijusios gyvenimo kokybès dimensijų ìsivertinimo: fizinè gerovè $(r=0,454, p=0,000)$, psichologinè gerovè $(r=0,360, p=0,000)$, savarankiškumas $(r=0,236$, $\mathrm{p}=0,000)$, santykiai su tèvais ir gyvenimas šeimoje $(\mathrm{r}=0,286$, $\mathrm{p}=0,000)$, finansiniai ištekliai $(\mathrm{r}=0,197, \mathrm{p}=0,000)$, socialinis palaikymas ir bendraamžiai $(\mathrm{r}=0,168, \mathrm{p}=0,000)$, mokyklos aplinka $(\mathrm{r}=0,262, \mathrm{p}=0,000)$, socialinis prièmimas (patyčios) $(\mathrm{r}=0,042, \mathrm{p}=0,000)$. Tai reiškia, jog visas prieš tai išvardintas vaikų su sveikata susijusios gyvenimo kokybès dimensijas aukštesniais balais įsivertino tie vaikai, kurie geriau vertino 
savo sveikatą. Statistiškai reikšminga netiesioginè koreliacija nustatyta tarp subjektyviojo sveikatos vertinimo ir nuotaikos bei emocijų dimensijos $(r=0,004, p=0,000)$. Šią dimensiją aukštesniais balais įsivertino tie vaikai, kurie subjektyviai savo sveikatą vertino prasčiau.

Tẻvų nuomoné apie jų vaikų subjektyvujị sveikatos ir su vaikų sveikata susijusios gyvenimo kokybès vertinimo ryši. Tyrimo metu nustatyta tendencija, kad tèvai, kurių manymu, vaikai vertina savo sveikatą labai gerai ir puikiai, aukštesnius balus skyrè šioms su vaikų sveikata susijusioms gyvenimo kokybès dimensijoms: nuotaikų ir emocijų $(r=0,331, p=0,000)$ bei socialinio prièmimo (patyčių) $(\mathrm{r}=0,131, \mathrm{p}=0,000)$. Šie tèvai dažniau atsake, kad jų vaikai jaučiasi gerai, yra geros nuotaikos, nepatiria patyčių, jaučiasi priimti ir gerbiami draugų. Kuo geriau vaikai vertino savo sveikatą, tuo žemesnius balus jų tèvai skyrè: fizinès gerovès $(\mathrm{r}=-0,458, \mathrm{p}=0,000)$, psichologinès gerovès $(\mathrm{r}=-0,367$, $\mathrm{p}=0,000)$, savarankiškumo $(\mathrm{r}=-0,110, \mathrm{p}=0,000)$, santykių su tèvais ir gyvenimo šeimoje $(r=-0,110, p=0,000)$, finansinių išteklių ( $\mathrm{r}=-0,218, \mathrm{p}=0,000)$, socialinio palaikymo ir bendraamžių $(\mathrm{r}=-0,218, \mathrm{p}=0,000)$, mokyklos aplinkos $(\mathrm{r}=$ $-0,233, p=0,000)$ dimensijoms. Ši tèvų grupé dažniau manè, kad jų vaikai fiziškai nepasirengę, išsekę, turi mažai energijos, nejaučia gyvenimo malonumo, jaučia nepasitenkinimą gyvenimu, jaučiasi ribojami, prislègti, priklausomi, kalbant apie santykius su tėvais, nepastebėti, kankinami vienišumo jausmo, tèvus vertina kaip nepasiekiamus, nesąžiningus, jaučia finansinio nepasitenkinimo jausmą, finansiniai šaltiniai neleidžia gyventi taip, kaip norètų, mano, kad jų vaikas jaučiasi nepriimtas, atstumtas, nepalaikomas bendraamžių, negali jais pasikliauti. Šių tėvų nuomone, jų vaikas nemėgsta mokyklos ir mokytojų, vaikus kankina negatyvūs jausmai mokyklai.

\section{Išvados}

1. Du trečdaliai vaikų nurodè neturintys sveikatos sutrikimų, tačiau tik trečdalis savo sveikatą įvertino puikiai ir labai gerai. Tai rodo, kad vaikų sveikatai svarbus ne tik ligos ar negalios nebuvimas, bet ir psichologiniai bei socialiniai veiksniai.

2. Vaikai, kurių subjektyvusis sveikatos vertinimas geresnis, geriau vertino fizinès gerovès, psichologinès gerovès, savarankiškumo, santykių su tèvais ir gyvenimo šeimoje, finansinių išteklių, socialinio palaikymo ir bendraamžių, mokyklos aplinkos, socialinio prièmimo gyvenimo kokybės dimensijas.

3. Kuo geriau vaikas vertino savo sveikatą, tuo statistiškai reikšmingai aukštesnius vertinimus tėvai skyrè nuotaikų ir emocijų bei socialinio prièmimo (patyčių) dimensijoms; kuo geriau vaikas vertino savo sveikatą, tuo statistiškai reikš- mingai žemesnius vertinimus tėvai skyrẻ fizinès gerovès, psichologinès gerovès, savarankiškumo, santykių su tèvais ir gyvenimo šeimoje, finansinių išteklių, socialinio palaikymo ir bendraamžių, mokyklos aplinkos dimensijų vertinimui.

\section{Literatūra}

1. Albrecht G. Using subjective health assessments in practice and policy making. Health care analysis. Journal of Health Philosophy and Policy 1996;4(4):284-292.

https://doi.org/10.1002/(SICI)1099-1042(199611)4:4<284::AIDHCA194>3.0.CO;2-W

2. Bradshaw C, Atkinson S, Doody O. Employing a qualitative description approach in health care research. Sage Journals 2017. https://doi.org/10.1177/2333393617742282

3. Butikis M. Sveikatos sąlygojamos gyvenimo kokybės ir amžiaus sąveika. Daktaro disertacija. Vilniaus universitetas, 2009.

4. Butvilas D., Kriščiūnas A., Endzinienè M., Jurkevičienė G., Švedaitė-Sakalauskẻ B. Jaunų žmonių, sergančių epilepsija, gyvenimo pilnatvè. Neurologijos seminarai, 2010;14(44):86-92.

5. Cleary PD. Subjective and objective measures of health: which is better when? Journal of Health Services Research Policy 1997;2(1):3-4. https://doi.org/10.1177/135581969700200102

6. Franz CE, Finkel D, Panizzon MS, et al. Facets of subjective health from early adulthood to old age. Journal of Aging and Health 2017;29(1):149-171. https://doi.org/10.1177/0898264315625488

7. Furmonavičius T. Su sveikata susijusios gyvenimo kokybės tyrimų metodologiniai aspektai. Medicina (Kaunas), 2004;40(6):509-16.

8. Grubliauskienė J. Edukacinė šeimos dimensija su sveikata susijusios vaikų gyvenimo kokybės vertinimo kontekste. Daktaro disertacija. Klaipėdos universitetas, 2019.

9. Juozulynas A., Prapiestis J., Jurgelėnas A., Valeikienė V., Savičiūtė R., Migline V. Pensijinio amžiaus žmonių gyvenimo kokybės tyrimai Vilniaus mieste. Gerontologija, 2009;10(2), 83-91.

10. Kaplan RM. The significance of quality of life in health care. Qual Life Res 2003;12(S1):3-16. https://doi.org/10.1023/A:1023547632545

11. Kidscreen Europe group. The KIDSCREEN questionnaires. Quality of life questionnaires for children and adolescents. Handbook. Pabst Science Publishers 2006.

12. Kymantienė J., Bulotaitė L. Kompleksinio sveikatos vertinimo modelis. Visuomenès sveikata, 2016;2(73):46-53.

13. Knighting K, Rowa-Dewar N, Malcolm C, Kearney N, Gibson F. Children's understanding of cancer and views on health-related behavior: a 'draw and write'study. Child: care, health and development 2011;37(2):289-299. https://doi.org/10.1111/j.1365-2214.2010.01138.x

14. Kostmann E, Nilsson L. Children's perspectives on health: what makes children feel good according to themselves? Internatio- 
nal Journal of Education, 2012;4(1):1-11.

https://doi.org/10.5296/ije.v4i1.914

15. Krančiukaitė D., Rastenytė D., Jurènienė K., Šopagienė D. Persirgusiujų galvos smegenų insultu gyvenimo kokybè. Medicina, 2007;43(9):736-745.

https://doi.org/10.3390/medicina43090095

16. Luneckaitè Ž. Onkologinių ligonių gyvenimo kokybès sąsajos su socialiniais-psichologiniais veiksniais ir paliatyviaja priežiūra. Daktaro disertacija. KMU, 2009.

17. Mikaliūkštienè, A. Sergančiụjų 2-ojo tipo cukriniu diabetu gyvenimo kokybès ir emocinès būsenos ryšys su ligos ir socialiniais veiksniais. Daktaro disertacija. Vilniaus universitetas, 2011.

18. Paul P, Hakobyan M, Valtonen H. The association between self-perceived health status and satisfaction with healthcare services: evidence from Armenia. BMC Health Services Research 2016;16(1):67.

https://doi.org/10.1186/s12913-016-1309-6

19. Rajmil L, Alonso J, Berra S, et al. Use of a children questionnaire of health-related quality of life (KIDSCREEN) as a measure of needs for health care services. Journal of Adolescent Health 2006;38(5):511-518.

https://doi.org/10.1016/j.jadohealth.2005.05.022

20. Ravens-Sieberer U, Schmidt S, Gosch A, Erhart M, Petersen C, Bullinger M. Measuring subjective health in children and adolescents: results of the European KIDSCREEN/DISABKIDS project. Psychosoc Med 2007;4:Doc08. https:/www.ncbi. nlm.nih.gov/pubmed/19742297.

21. Rezende BA, Lemos SMA, Medeiros AM. Quality of life and health self-perception in children with poor school performance. Rev Paul Pediatr 2017;35(4):415-421.

https://doi.org/10.1590/1984-0462/;2017;35;4;00009

22. Servetkienė V. Gyvenimo kokybės daugiadimensis vertinimas, identifikuojant kritines sritis. Daktaro disertacija. Vilnius: Mykolo Romerio universitetas, 2013.

23. Starkauskienė V. Gyvenimo kokybès veiksniai ir jos kompleksinio vertinimo modelis. Daktaro disertacija. VDU, 2011.

24. Staškutė I. Su sveikata susijusios gyvenimo kokybės samprata, stebėsenos ir vertinimo metodai bei reikšmė sveikatos politikoje. Sveikatos politika ir valdymas, 2014;1(6):7-19.

https://doi.org/10.13165/SPV-14-1-6-01

25. Tamutienè I. Vyresnio amžiaus moterų patiriama prievarta ir sąsajos su jų gyvenimo kokybe Lietuvoje. Gerontologija, 2011;12(2):97-103.

26. Vik MH, Carlquist E. Measuring subjective well-being for policy purposes: the example of well-being indicators in the WHO "Health 2020" framework. Scandinavian Journal of Public Health 2018;46(2):279-286. https:/ezproxy.biblioteka. ku.1t:4409/doi/full/10.1177/1403494817724952.

https://doi.org/10.1177/1403494817724952
27. 2014 m. Lietuvos gyventojų sveikatos statistinio tyrimo rezultatai (2015). Lietuvos statistikos departamentas. https://osp. stat.gov.lt/services-portlet/pub-edition-file?id=20908.

\section{CONCEPTUALIZATION OF RELATIONSHIP BETWEEN CHILDREN' SUBJECTIVE HEALTH ASSESSMENT AND QUALITY OF LIFE \\ J. Grubliauskienė, R. Vaičekauskaitè, A. Kurienė, N. Fatkulina}

Keywords: subjective health assessment, quality of life, children.

\section{Summary}

Person's subjective health assessment has been recognized as important for health promotion and medicine practice since seventh decade of XXth century. We face a challenge to have holistic picture of various studies due to a lack of methodological consistency and theoretical conceptualization. Some research support notion that subjective health assessment could be as supplementary to medical data. Another research claim the importance of subjective health assessment almost equal to medical diagnosis. Subjective health assessment is a social phenomenon with high complexity of different factors. We claim quality of life approach could help to understand a variety of factors as a system. The relationship between quality of life and subjective health assessment started to be blurred, when "many non-clinical data about health is considered as quality of life" [3]. Health is considered to be one of the most important dimensions of quality of life, however, it does not necessarily absolutely determine the quality of life. This is demonstrated by cases when people with disabilities evaluate their quality of life well [7, 22-24]. In order to conceptualize the relationship between subjective health assessment and quality of life, a concept of health-related quality of life is developed that expresses how people 'perceive and respond to their health and health-related factors such as physical, functional, emotional, and mental wellbeing, and factors that are not directly related to health, such as work, family, friends, etc. "[24]. To address the problem of conceptualization on subjective health assessment, the authors of the article develops an analysis of the relationship between factors of subjective health assessment and quality of life of 1,763 children and 1,564 parents children, who responded to Lithuanian version of KIDSCREEN52 questionnaire [8]. The relationship between subjective health assessment and quality of life is evidenced by the results of the results trends: two-thirds of children reported having no health problems, but only one-third rated their health as excellent and very good. This indicates that not only the absence of disease or disability is important for children's health assessment, but also the psychological and social factors that shape health-related quality of life.

Correspondence to: grubliauskiene.jurate@gmail.com

Gauta 2020-01-23 